\title{
Digital learning Initiatives, Challenges and Achievement in Higher Education in Nepal Amidst COVID-19
}

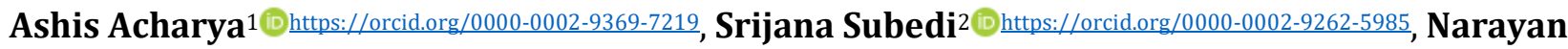
Gyawali 3 @ https: //orcid.org/0000-0001-7810-7260, Nabaraj Poudyal4@https://orcid.org/0000-0002-1289-9629, Ganesh Lamichhane 5 - https://orcid.org/0000-0002-4352-7457, Govinda Bastola6@ https://orcid.org/0000-0001-9850-5098, Babita Aryal $^{7}$ ○htps://orcid.org/0000-0001-9731-8485, Bibek Raj Bhattarai 8 - https://orcid.org/0000-0003-0259-5004, Bikash Adhikari ${ }^{9}$ https: //orcid.org/0000-0002-5532-6644, Rishab Marahatha $10 @$ https://orcid.org/0000-0002-9065-159X, Madhabi Bhatta 11 - https://orcid.org/0000-0001-9085-7101, Mohan Paudel ${ }^{12}$-https://orcid.org/0000-0001-8558-3505, Niranjan Parajuli13* - https://orcid.org/0000-0002-9233-6489

${ }^{1}$ Central Department of Geology, Tribhuvan University, Kirtipur, Kathmandu, Nepal; ${ }^{2,6}$ Central Department of Statistics, Tribhuvan University, Kirtipur, Kathmandu, Nepal; ${ }^{3}$ Rural Education and Environment Development Center, Lalitpur, Nepal; ${ }^{4}$ Department of Statistics, Amrit Campus, Tribhuvan University, Kathmandu, Nepal; 5,7, 8,9,10,13Biological Chemistry Lab, Central Department of Chemistry, Tribhuvan University, Kirtipur, Kathmandu, Nepal; ${ }^{11}$ Rise Nepal Research Foundation, Kathmandu, Nepal; ${ }^{12}$ Central Department of Education, Tribhuvan University, Kirtipur, Kathmandu, Nepal

*e-mail: niranjan.parajuli@cdc.tu.edu.np

\section{Article Information}

Received: June 12, 2021

Revised: August 01, 2021

Accepted: August 07, 2021

Online: August 19, 2021

\section{Keywords}

Education; Students' perception;

Internet access

\begin{abstract}
The COVID-19 pandemic has affected higher education institutions (HEIs) worldwide and reshaped the existing educational system. Due to travel constraints and physical separation, there has been a global shift toward distance learning, and Nepal is no exception. This research intends to assess the practicality of online education by evaluating learners' experiences amidst COVID-19. A cross-sectional study was directed among HEIs students in Nepal using selfstructured questionnaires. Our study revealed that $64.6 \%$ of the respondents were unsatisfied with online classes. More than half of the respondents (53.4\%) use cell phones for online studies. Online education was reported to be unappealing to $28.8 \%$ of respondents. Variables such as age group ( $p=0.05)$, enjoying class $(p<0.001)$, hours spent for an online class in a day ( $p=0.05)$, and period for educational work using an electronic device $(p=0.1)$ were found significant with satisfaction level using both bivariate test and inferential test of univariate binary logistics regression. The challenges and opportunities encountered among students and faculties are highlighted along with the recommendations for fortifying communication in online-based teaching/learning.
\end{abstract}

\section{INTRODUCTION}

COVID-19 has resulted in the closure of several schools and universities worldwide, affecting a billion learners globally (Viner et al., 2020). Due to the emergence of series of the wave of the pandemic, Nepal's educational institutions have been temporarily closed down leading to enormous anxiety and uncertainty and estimated that nearly nine million students in Nepal were affected (UNESCO, 2021). The closure of educational institutions for a considerably long period initiate a change in the education 
system and led to the notable rise of online learning, whereby teaching and learning were undertaken remotely and on digital platforms.

E-learning is a form of distance learning, which has long been a part of the education system globally, replicating the physical "Brick and Mortar" classroom (Burac et al., 2019; Nguyen, 2015). Amid the COVID-19 pandemic, e-learning has replaced traditional educational techniques and has become an obligatory component of all educational institutions in the world, as it offers students elasticity in where and when they learn (Maatuk et al., 2021; Radha, 2020). Different countries start to adopt various Learning Management Systems (LMS) and Cloud Computing-based resources to aid the educational process. Countries with huge populations, such as China and India, also started online learning protocols by mobilizing the existing materials and resources at provincial and national platforms (Azzi-Huck \& Shmis, 2020). Likewise, developing countries such as Nepal have also been utilizing different platforms like Microsoft teams, Google Meet, Zoom, etc., as online teaching methods of lower to a higher level. During this period, HEIs of Nepal have been adopting the online platform and somehow struggling to fulfill the required courses for the exam and their degrees as well. To facilitate the mobile data package for learners and to expedite the teaching-learning and research activities in higher education, an agreement has been signed between University Grants Commission (UGC) and Nepal Telecom (NT) (UGC, 2020a). However, the sudden and forceful transition from offline to online learning systems has posed some shorts of stress among educational professionals (Espino-Díaz et al., 2020).

The pandemic has exposed the shortcomings of the current higher education (HE) system and the need for trained educators in digital technology to adapt to the rapidly changing education climate of the world (Rashid \& Yadav, 2020). The educational institutions in countries which are technologically advanced promote their technological competencies, however the lack of network infrastructures, computers, and internet access is making challenges for implementing distance learning in the least developing countries (LDCs) (Tadesse \& Muluye, 2020). COVID-19 has a disproportionately negative socioeconomic impact on students from poor and vulnerable families, as observed in Nigeria (Azubuike et al., 2021). Improper and deficient technological and practical fundamentals have been causing problems for all students, instructors, and other involved individuals (Zarei \& Mohammadi, 2021). Patricia Aguilera-Hermida (2020) found that after the transition to online classes, motivation, selfefficacy, and cognitive engagement decreased, while only the use of technology increased; however, Lorenza \& Carter (2021) found that students gained confidence and resilience during the emergency online teaching period. In the case of developing countries, online education which has become the new normal, courtesy of COVID-19, is currently facing different kinds of challenges such as lack of resources, poor national infrastructure, course delivery problems, problems facing students, and cybersecurity problems (Anwar et al., 2020; Oyedotun, 2020; Zarei \& Mohammadi, 2021; Adnan \& Anwar, 2020). Technical issues are the most important, followed by teachers' lack of technical and administrative skills and their teaching style improperly adapted to the online environment (Coman et al., 2020). Besides, inhome environment settings, faculties face a lack of necessary facilities, external distraction, and family interruption during teaching. Moreover, major barriers, a lack of training, financial unpreparedness, a lack of technical support, and a lack of clarity and direction were also reported (Agormedah et al., 2020; Loshi et al., 2020; Zhang et al., 2020). A Canadian study mentioned that teachers' cognitive and emotional

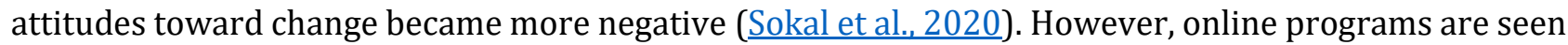
as effective forms of teaching during the COVID-19 due to several benefits for learners such as time savings, cost savings, and flexibility (Motte-Signoret et al., 2021).

The issue of the COVID-19 and its impact on the higher education industry is a growing topic of discussion worldwide. Several studies have been conducted recently to explore the effectiveness of elearning in educational sectors globally (Al-Azzam et al., 2020; Kirsch et al., 2021; Mishra et al., 2020; Tang et al., 2021). However, in Nepal, not many studies have been done to investigate the factors for the effectiveness of the online mode of classes and perception of faculties and students during the COVID19 pandemic (Chaudhary, 2021; Dawadi et al., 2020; Neupane et al., 2020; Sigdel et al., 2021; Tuladhar et al., 2020). A study argued that online education is highly beneficial in promoting online research, connecting the practitioners to the global community, getting huge and authentic resources of knowledge required for professional and academic endeavors, and making them self-disciplined (Paudel, 2020). Similarly, the majority of faculty members thought that the online class setting was participatory (95.2\%), although it was not as effective $(86.5 \%)$ as a live classroom, according to data 
collected from Nepalese dentistry colleges (Shrestha et al., 2020). According to an online questionnaire survey of 226 students of Lumbini Medical College, Nepal, two-thirds of the students thought online classes were worse than traditional classroom teaching and $77.8 \%$ of the students favored traditional classroom teaching in the future (Nepal et al., 2020). Likewise, similar results were reported on the issues of electricity and internet access among nursing students (Koirala et al., 2020; P. Thapa et al., 2021). However e-learning in HEIs in Nepal confronted a few obstructions during the pandemic mode, many authors in several studies believed that this type of transition of conventional to online teachinglearning mode certainly provides ample opportunities for learners and teachers (Koirala et al., 2020;

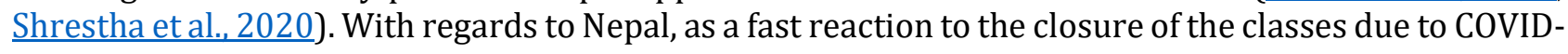
19 , universities and some private colleges initiated online education systems for the first time. Notwithstanding, the effect of the prolonged lockdown and the pandemic fatigue on students and their academic experience in Nepal is yet indistinct because of the absence of sufficient examination. This study aims to determine the efficacy of e-learning in Nepalese HEIs amidst COVID-19. Furthermore, by extensive literature surveys, the authors studied various problems and opportunities, and some recommendations were provided to strengthen the online teaching-learning strategy in the long haul.

\section{Digital Learning in Nepal}

Prior schooling frameworks utilized different multimedia CDs and DVDs as e-learning in Nepal. The College of Education started an adult education program through radio in 1958 which was considered to have been the first initiative for distance education. Likewise, as provisioned in National Education Commission 1993, the Distance education center (DEC) was set up under the ministry of education (MoE) in 1994. The center conducted teacher training and education awareness programs through radio broadcasting (Pangeni, 2017). The present decade has seen sensational development in the utilization of online, blended, and approaches of distance learning in HEIs in Nepal as the internet penetration and availability of electronic devices are quickly expanding (Thapa, 2020). There were 10.78 million internet users and the internet penetration in Nepal stood at 36.7\% in January 2021 (Figure 1). The data showed that the number of internet users increased by 657 thousand (+5.5\%) between 2020 and 2021 (DataReportal, 2021; Statista, 2021). According to Ambient Insight Research, out of the 122 countries, only 15 countries including Nepal show a positive (more than 15\%) growth rate for self-paced e-learning (Figure 2) (Docebo, 2017). Nepal Open University established in 2016 is offering its programs online using LMS. Other universities programs are running in face-to-face mode. In addition, several universities such as TU and KU, offer some courses online or in blended mode. Moreover, Nepal Government has launched its first governmental e-learning portal that appears as an open library for Nepalese students (GoN, 2020). Recently, Sharma \& Bhatta (2018) investigated the effectiveness of implementing E-Learning in the Far Western Region, one of the economically backward regions of Nepal. E-learning has gained an unprecedented acceleration due to the impact of the present pandemic. Anyway, Nepali higher education culture is on the way to making a grand shift towards adapting innovative technology due to the globally increasing E-learning market.

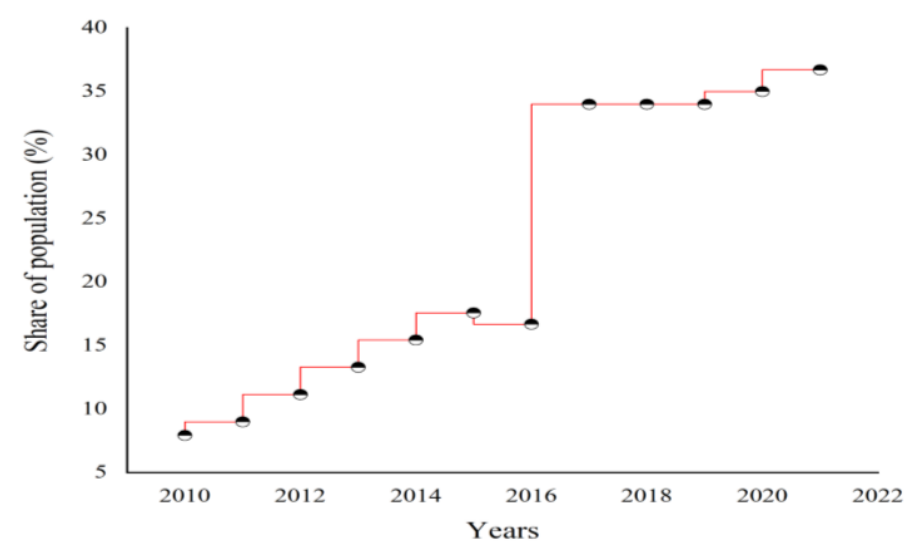

Figure 1. The rate of internet penetration in Nepal from 2010 to 2021

(DataReportal, 2021; Statista, 2021)

IJAE Page 417 


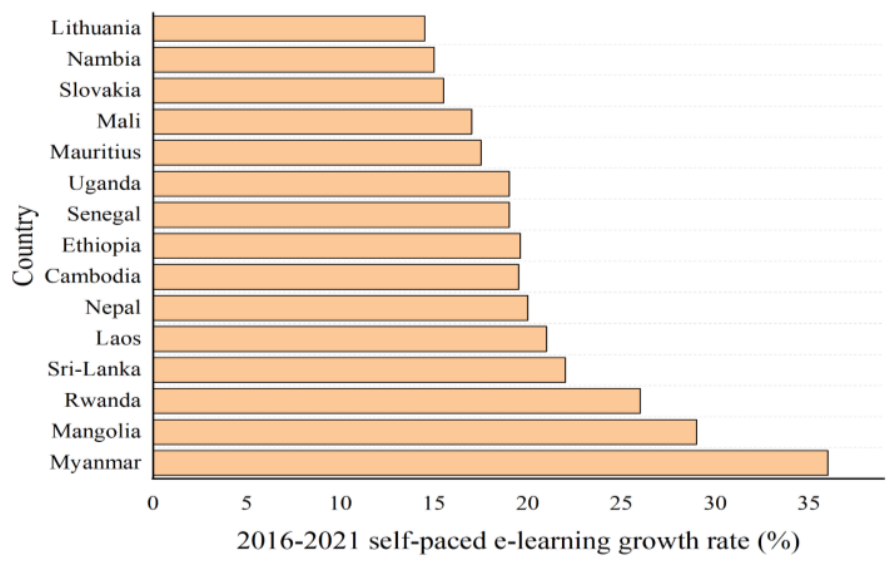

Figure 2. 2016-2021 top fifteen worldwide self-paced e-learning five-year growth rates (Data adapted from Docebo, 2017)

\section{METHODS}

A cross-sectional study was carried out in the present study where students of HEIs across the country were taken as a population of the study. An online survey was performed to compile the qualitative and quantitative responses from participants where pre-structured questionnaires were developed and were set in google forms and they were distributed via social media platforms. A random sampling technique was used to select the sample. Only 410 completely filled-up forms were taken into consideration as a sample.

Statistical analysis including descriptive and inferential methods was performed using IBM SPSS Statistics (Windows Version 25.0). Descriptive statistics were generated, and the Chi-square test, independent sample t-test \& ANOVA were used to examine differences between groups. The significance level was stated as $P<0.10$. Further, an inferential test was performed using univariate binary logistics regression analysis only for those significant variables which were found to be significant using chisquare test, t-test \& ANOVA.

\section{Dependent variable}

The outcome variable of the study is satisfaction with online education among the participants of higher educational institutions. For this, 10 questions on a 4-point Likert scale consisting of strongly agree, agree, disagree, and strongly disagree were used for representing the satisfaction and perceptions. The questionnaires are presented in Table 1. Cronbach's alpha value for testing the reliability of 10 questions was performed and Cronbach's alpha was obtained as 0.753 . Thus, the reliability value is good. For further analysis, responses agree and strongly agree were coded as "1" and disagree and strongly disagree were coded as "0". Summated scores of ten items were calculated and participants were classified as being satisfied and unsatisfied using median value as the cut-off point. Where median score was obtained 7 and scores $\leq 7$ was considered as unsatisfied and score from 7-10 was considered as satisfied. Out of 410 respondents, $64.6 \%$ of them were unsatisfied with the online classes and only $35.4 \%$ reported that they were satisfied.

Table 1. Frequency distribution of respondents and weighted mean based on their responses during online classes in HEIs

\begin{tabular}{lccccc}
\hline \multirow{2}{*}{ Queries } & \multicolumn{4}{c}{ Response Frequency (\%age) } & Weighted \\
\cline { 2 - 6 } & $\begin{array}{c}\text { Strongly } \\
\text { Agree }\end{array}$ & Agree & Disagree & $\begin{array}{l}\text { Strongly } \\
\text { Disagree }\end{array}$ \\
\hline Easy access to the internet & $77(18.8)$ & $210(51.2)$ & $96(23.4)$ & $27(6.6)$ & 2.82
\end{tabular}




\begin{tabular}{|c|c|c|c|c|c|}
\hline \multirow[b]{2}{*}{ Queries } & \multicolumn{4}{|c|}{ Response Frequency (\%age) } & \multirow{2}{*}{$\begin{array}{l}\text { Weighted } \\
\text { Mean }\end{array}$} \\
\hline & $\begin{array}{l}\text { Strongly } \\
\text { Agree }\end{array}$ & Agree & Disagree & $\begin{array}{l}\text { Strongly } \\
\text { Disagree }\end{array}$ & \\
\hline $\begin{array}{l}\text { Have no interruption of electricity } \\
\text { and internet during online class }\end{array}$ & $39(9.5)$ & $112(27.3)$ & $202(49.3)$ & $57(13.9)$ & 2.32 \\
\hline $\begin{array}{l}\text { Comfortable using online class } \\
\text { instead of regular class }\end{array}$ & $25(6.1)$ & $120(29.3)$ & $211(51.5)$ & $54(13.2)$ & 2.28 \\
\hline $\begin{array}{l}\text { Need a face-to-face contact with an } \\
\text { instructor }\end{array}$ & $71(17.3)$ & $266(64.9)$ & $67(17.3)$ & $6(1.5)$ & 2.98 \\
\hline $\begin{array}{l}\text { Able to manage study time } \\
\text { effectively and submit assignments } \\
\text { on time }\end{array}$ & $30(7.3)$ & $232(56.6)$ & $130(31.7)$ & $18(4.4)$ & 2.66 \\
\hline $\begin{array}{l}\text { Comfortable with electronic } \\
\text { communication }\end{array}$ & $30(7.3)$ & $213(52.0)$ & $140(34.1)$ & $27(6.6)$ & 2.60 \\
\hline Ask the instructor for any queries & $33(8.0)$ & $288(70.2)$ & 85 (20.7) & $4(1.0)$ & 2.85 \\
\hline Attend class regularly & $65(15.9)$ & $209(51.0)$ & $116(28.3)$ & $20(4.9)$ & 2.77 \\
\hline $\begin{array}{l}\text { Attention is on the screen during } \\
\text { the entire class }\end{array}$ & $42(10.2)$ & $211(51.5)$ & $116(32.7)$ & $20(5.6)$ & 2.66 \\
\hline $\begin{array}{l}\text { Instructor well deliver course } \\
\text { content using technology }\end{array}$ & $38(9.3)$ & $256(62.4)$ & $97(23.7)$ & $19(4.6)$ & 2.76 \\
\hline
\end{tabular}

\section{Independent Variables}

The survey uncovered that the greater part of the respondents (52.9\%) were female, while the leftover respondents were male. The age bunch 23-27 had the highest percentage of respondents $(60.2 \%)$, trailed by respondents under 22 years old (37.6\%), while just about $2.2 \%$ of respondents were more than 28 years old. Similarly, the maximum number of respondents (56.1\%) educational level was master's degree and above and 43.9\% were studying bachelor's degree. The question was asked in the survey regarding their device used for online classes, where more than half of the total respondents $(53.4 \%)$ reported that they use cell phones for their online study. $45.1 \%$ of the respondents reported that they use laptops for their study and only $1.5 \%$ used a tab/pad. It was also asked in the survey whether the respondents were enjoying the virtual classes or not, and in that particular question respondents reporting no were $28.8 \%, 36.1 \%$ of the respondents were not sure and responded maybe, whereas only $35.1 \%$ of the respondents said yes that they were enjoying the virtual classes. It was observed that the maximum number of hours participants spend for educational work on electronic devices was 16 hours and the minimum was 1 hour and the mean was 3 hours. Maximum (59.8\%) participants spend less than 3 hours in a virtual class, $16.1 \%$ of the respondents spend 3-7 hours in a virtual class, only $2.0 \%$ of the respondents spend $\geqslant 8$ hours in a virtual class. About $22.2 \%$ of the respondents have no access to online classes.

Similarly, $60.5 \%$ of the respondents were from the science stream, while $18.5 \%$ were from applied science fields such as medicine, engineering, animal science, agriculture, and so on, according to the statistics. Management accounted for over $12 \%$ of the respondents, while other sectors such as arts, education, law, and others accounted for only $8.8 \%$. Furthermore, Tribhuvan University had the highest percentage age of responses in the poll (83.2\%), with the rest coming from other universities such as Pokhara University, Kathmandu University, and so on. 


\section{Bivariate Analysis}

In this study, bivariate analysis is carried out to explore the relationship of satisfaction level of HEI students in regards to online classes with various downright factors by utilizing the method of crosstabulation.

Table 2. Satisfaction level of HEI learners regarding online classes concerning different categorical variables

\begin{tabular}{|c|c|c|c|c|}
\hline \multirow{3}{*}{ Variables } & \multirow{3}{*}{ Categories } & \multicolumn{2}{|c|}{ Satisfaction level } & \multirow{3}{*}{$\begin{array}{c}\text { Chi-square } \\
\text { (p-value) }\end{array}$} \\
\hline & & Satisfied & Unsatisfied & \\
\hline & & $\begin{array}{c}\text { Number } \\
\text { (\%) }\end{array}$ & $\begin{array}{c}\text { Number } \\
(\%)\end{array}$ & \\
\hline \multirow[t]{3}{*}{ Age Group } & up to 22 years & $53(34.4)$ & $101(65.6)$ & \multirow[t]{3}{*}{$7.241\left(0.027^{*}\right)$} \\
\hline & 23-27 years & $85(34.4)$ & $162(65.6)$ & \\
\hline & above 28 years & $7(77.8)$ & $2(22.2)$ & \\
\hline \multirow[t]{2}{*}{ Gender } & Male & $71(36.8)$ & $122(63.2)$ & \multirow[t]{2}{*}{$0.322(0.570)$} \\
\hline & Female & $74(34.1)$ & $143(65.9)$ & \\
\hline \multirow[t]{4}{*}{ Faculty } & Pure Science & $87(35.1)$ & $161(64.9)$ & \multirow[t]{4}{*}{$2.324(0.508)$} \\
\hline & Applied Science & $23(30.3)$ & $53(69.7)$ & \\
\hline & Management & $19(38)$ & $31(62)$ & \\
\hline & Others & $16(44.4)$ & $20(55.6)$ & \\
\hline \multirow[t]{2}{*}{ Level of Study } & Bachelors & $58(32.2)$ & $122(67.8)$ & \multirow[t]{2}{*}{$1.387(0.239)$} \\
\hline & $\begin{array}{l}\text { Masters and } \\
\text { above }\end{array}$ & $87(37.8)$ & $143(62.2)$ & \\
\hline \multirow[t]{3}{*}{ Enjoying Class } & No & $10(8.5)$ & $108(91.5)$ & \multirow{3}{*}{$\begin{array}{l}82.557 \\
\left(0.000^{*}\right)\end{array}$} \\
\hline & Maybe & $46(31.1)$ & $102(68.9)$ & \\
\hline & Yes & $89(61.8)$ & $55(38.2)$ & \\
\hline \multirow[t]{4}{*}{$\begin{array}{l}\text { Hours spend on online } \\
\text { classes a day }\end{array}$} & $\begin{array}{l}\text { No access to } \\
\text { online class }\end{array}$ & $22(24.2)$ & $69(75.8)$ & \multirow[t]{4}{*}{$8.815\left(0.032^{*}\right)$} \\
\hline & $<3$ hours & $95(38.8)$ & $150(61.2)$ & \\
\hline & 3-7 hours & $23(34.8)$ & $43(65.2)$ & \\
\hline & $\geq 8$ hours & $5(62.5)$ & $3(37.5)$ & \\
\hline \multirow[t]{2}{*}{ University } & $\begin{array}{l}\text { Tribhuvan } \\
\text { University }\end{array}$ & 119 (34.9) & $222(65.1)$ & \multirow[t]{2}{*}{$0.195(0.659)$} \\
\hline & Others & $26(37.7)$ & $43(62.3)$ & \\
\hline
\end{tabular}

*Significant at $5 \%$ 
Table 3. Statistical test of significance and results using T-test and ANOVA

\begin{tabular}{|c|c|c|c|c|}
\hline Factors & Test & $\begin{array}{c}\text { p- } \\
\text { value }\end{array}$ & $\begin{array}{l}\text { Sig. level } \\
(\alpha)\end{array}$ & Results \\
\hline $\begin{array}{l}\text { Hours spend on educational } \\
\text { work using an electronic } \\
\text { device }\end{array}$ & t-test & 0.072 & 0.1 & $\begin{array}{l}\text { Significant among the satisfied } \\
\text { and unsatisfied group }\end{array}$ \\
\hline Device used & ANOVA & 0.001 & 0.01 & $\begin{array}{l}\text { Significant among cell phone, } \\
\text { laptop, and tab/pad users }\end{array}$ \\
\hline
\end{tabular}

From Table 2, it is seen that the greatest number of participants in the age group below 22 years $(65.6 \%)$ and of age group 23-27 years (65.6\%) were equally unsatisfied with the online classes and the variable is significant $(\mathrm{p}=0.027)$ at $5 \%$ level of significance. Similarly, from the cross-tabulation, it was observed that the maximum number of respondents (91.5\%) were not enjoying online classes and they were unsatisfied too. Enjoying online classes has a significant association with satisfaction level ( $\mathrm{p}<$ $0.001)$. Furthermore, hours spent on online classes in a day are also significantly associated $(p=0.032)$ with satisfaction level.

Females were more unsatisfied than males i.e., $65.9 \%$ versus $63.2 \%$ but the variable is insignificant at a $5 \%$ level of significance. It is seen that $69.7 \%$ of the respondents from applied science fields were unsatisfied with the online classes. We know that applied science is such a field where practical works are performed more than class lectures and the unsatisfied statistics also show that because students were unable to attend classes physically, they were unsatisfied. Unfortunately, the variable faculty of study is insignificant at a $5 \%$ level of significance. Similarly, the variables like level of study, enrolled university were also insignificant in the bivariate analysis.

Also, Table 3 shows that hours spent for educational work using electronic devices are significant using t-test at a $10 \%$ level of significance. Similarly, devices used for learning are also found significant using ANOVA at 1\%. It indicates that there is a significant difference in the satisfaction level of respondents regarding the devices used.

\section{Univariate Binary Logistics Regression}

Variables that were considered significant in bivariate analysis were further tested using univariate binary logistic regression, where a single variable was run at once.

Table 4. Results of univariate binary logistic regression

\begin{tabular}{|c|c|c|c|}
\hline Variables & B & Std. Error & p-value \\
\hline \multicolumn{4}{|l|}{ Age Group } \\
\hline$\leq 22$ years (above $28 \AA$ ) & -1.898 & 0.82 & $0.021^{*}$ \\
\hline 23-27 years (above 28 ®) & -1.898 & 0.813 & $0.02^{*}$ \\
\hline \multicolumn{4}{|l|}{ Enjoying class } \\
\hline No (Yes®) & -2.861 & 0.372 & $0^{*}$ \\
\hline Maybe (Yes $®)$ & -1.278 & 0.247 & $0^{*}$ \\
\hline \multicolumn{4}{|c|}{ Hours spent on online class in a day } \\
\hline No access to online class & -1.654 & 0.770 & $0.032 *$ \\
\hline
\end{tabular}




\begin{tabular}{lllll}
\hline & Variables & B & \multicolumn{1}{c}{ Std. Error } & p-value \\
\hline$<3$ hours & -0.968 & 0.742 & 0.192 \\
3-7 hours & -1.137 & 0.775 & 0.142 \\
$\begin{array}{l}\text { Hours spend on educational work using an } \\
\text { electronic device }\end{array}$ & 0.071 & 0.04 & $0.074^{* *}$ \\
\hline
\end{tabular}

${ }^{* * *}$ significant at $1 \%,{ }^{* *}$ significant at $10 \%,{ }^{*}$ significant at $5 \%$

From the univariate binary logistic regression, the variables like age group, enjoying class, hours spent on online class in a day, and hours spent for educational work using electronic devices were found significant (Table 4). Among all significant variables, enjoying online classes is the single variable that has a high Nagelkerke $\mathrm{R}^{2}$ of $26.9 \%$ i.e., about $27 \%$. This demonstrates that $27 \%$ of in variation in satisfaction level is singly explained by the variable enjoying the online classes. Additionally, to identify the nature of the relationship between satisfaction with the respondents' response about their enjoyment with online classes it was found that $r=0.447(p<0.001)$, which is a moderately positive correlation. It indicates that the more satisfied the students are, the more they enjoy the classes.

\section{CHALLENGES}

For the effective implementation of e-learning, physical facilities such as good internet connection and electronic devices are fundamental. Because of poor monetary conditions, uneven geological territory, and mal foundation, students have confronted difficulties with admittance to the internet facilities. Nepal lies in $123^{\text {rd }}$ position in the world in information communication and technology (ICT) service (Sharma \& Kim, 2016). This straightforwardly affects the legitimate execution of online education. Furthermore, the absence of an appropriate exercise plan and conveyance is also the main reason behind the ineffectiveness of the online classes. Another challenge for faculties and students to participate in online and virtual classes is the availability of electronic devices. Having a suitable electronic device (laptop) is a basic prerequisite for online and virtual classes but all the learners can't afford it as it costs high as the per capita income of a Nepali i.e. \$1155.143 (The World Bank, 2020). Couples of challenges such as dedicated space for studying and the feeling of anxiety have been reported in Jordan (Alsoud \& Harasis, 2021; Hebebci et al., 2020). Besides, poor network, internet addiction, and data privacy from the internet are other challenges that have affected the online learning system.

In addition, the COVID-19 truly affects learners' social, emotional passion, and mental prosperity (Dawadi et al., 2020). In such a condition the learners cannot develop a sense of confidence which is one of the most important factors for learning. Along with health conditions, a lack of a strictly implemented assessment system, punishment, and rewards demotivate learners to be serious towards accreditation of their course credit. Sun \& Chen (2016) explored that legitimate evaluation of the credit courses and the inspired association between the educator and learner is the most urgent piece of approving the learner's learning.

Other than students, faculties are the vital actors to bridge and complement learning during the pandemic. Bao (2020) reported that with the sudden emergence of the COVID-19, most faculties have faced the challenges of lacking online teaching experience, early preparation, or support from HEIs. With regards to Nepal, faculties argue that lack of sufficient professional development created challenges to develop effective resources, lesson design, interactive mode of delivery over online and virtual classes, and lack of willingness to adopt the new paradigm is another challenge as it requires extra effort and time. However, the insufficient professional development of faculties and institutional support is a common issue for underdeveloped countries (Farooq et al., 2020). Moreover, the challenges encountered in developing online classes include affordability, technology literacy, and self-motivation among faculty members in Nepal (National ICT Policy, 2015).

University Grants Commission (UGC), working in joints with the World Bank, gives assets/funds for conducting online classes and carrying out research projects in the universities and campuses. Under this e-learning funding program, eleven thousand four hundred poor students were supposed to be 
assisted. This program is expected to benefit eleven universities, 39 central departments, 19 schools, 115 constituent campuses, and 127 community campuses (UGC, 2020b). But this scenario has failed to implement as expected. Although online classes have been exercised in colleges across the country, it has not been as productive because of an absence of customary observing and evaluation.

Though online learning has been in practice, there is still uncertainty regarding examinations. The country's first and largest institution, the Tribhuvan University, is as yet unfit to lead both physical/online assessments inside the time frame and has lagged the academic years of thousands of students. With no appropriate rules, strategy, and course about the legitimate appraisal of the student's learning on an online platform, the path of HEIs is obscure and has made bedlam for everybody. Furthermore, for those previously stressed institutions in terms of finance, this pandemic threatened their solvency, forcing closures and merges. Moreover, the tension arises because the implementation of online education didn't cover the entire region. The problems that the HE ecosystem faces in implementing online education are summarized in Figure 3.

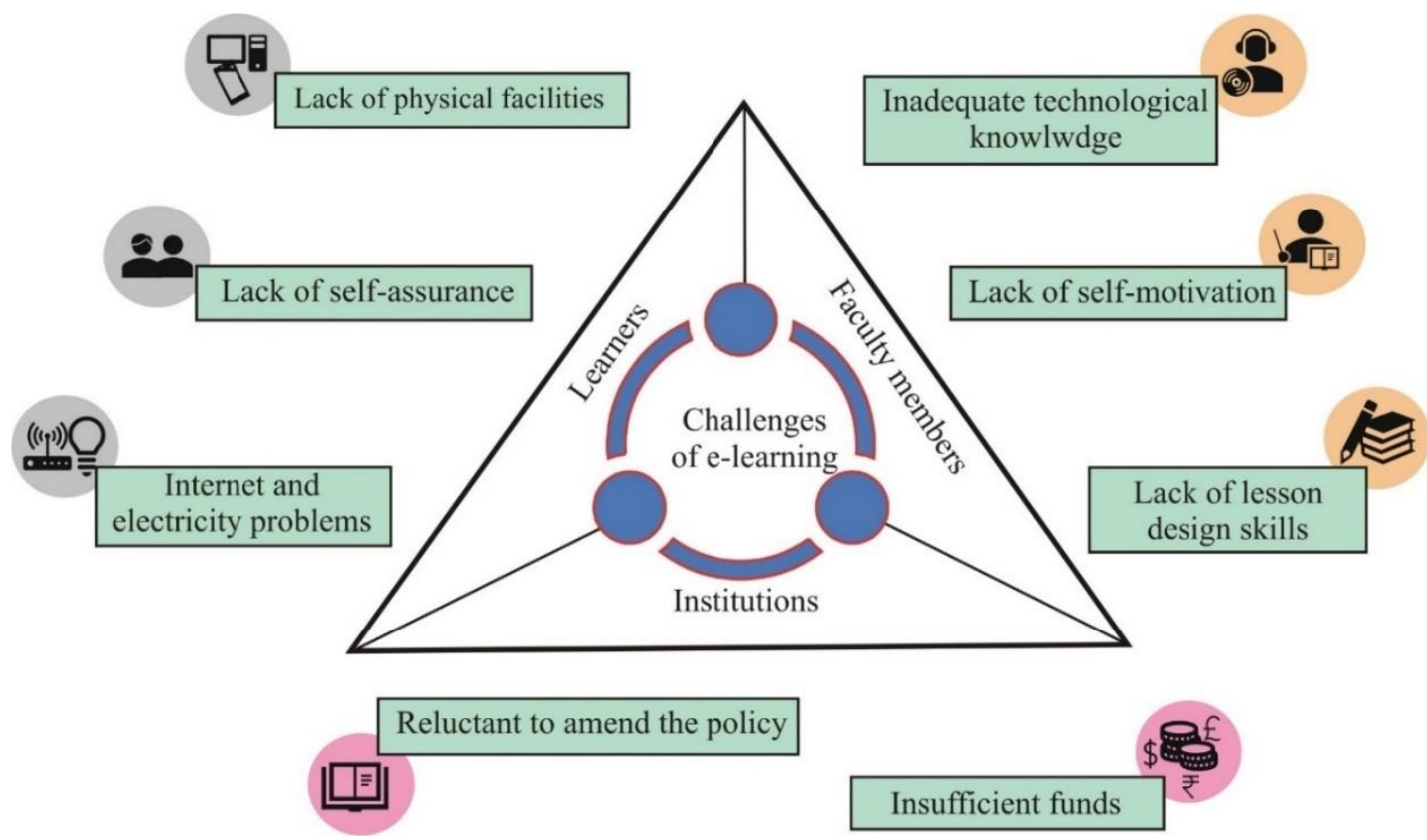

Figure 3. Challenges of E-learning in Nepal

\section{OPPORTUNITIES}

In the context of Nepal, students from rural areas migrate to urban areas to study the HEs which is expensive and not affordable to economically deprived students. Because of that, they are compelled to discontinue their study. If the e-learning initiatives become more effective with well-developed infrastructures, HEs become less expensive and affordable to families under poverty as there is a strong positive correlation between poverty and level of education (Brueckner \& Kim, 2001). E-learning platform provides the learners to develop different skills as reported by the study carried out by Huang in 1997. The study claims that virtual classes increase the time management skills, adaptation skills to international digital communities for the learners (Huang, 1997).

The e-learning drive has carried an opportunity among the resources to expertise up their innovative proficiency, powerful course plan, assets advancement, and intuitive method of delivery. Some of the facilities add that development and adaptation of the course curriculum, assignment and assessment system for the e-learning mode will allow them to show their excellence and competency among facilities and related departments.

In the public and government-run HEIs, the number of students is less in comparison to the number of students in the private HEIs since the people with higher income prefer private HEIs to public and government HEIs (Thapa, 2015). In this specific circumstance, if the public and government HEIs reinforce their e-learning platforms they can increase the attention of the students and diminishing the 
education disparities because of financial issues. This will be an opportunity to decrease the number of dropout students in the HEs due to poverty that can contribute to directly achieving SDGs goal number four which will ultimately increase the investment of the government to such institutions. In the long run, the virtual classes reduce the cost of HEIs and enhance pedagogy (Huang, 1997).

The government of Nepal has endorsed many policies to qualify the education sector for example implementation of Information Communication Technology (ICT) in education since 2000. Due to various factors such as lack of facilities, skillful faculties, and feeling of necessities in the faculties and institutions the implementation has not been much effective; therefore, this is the perfect time to skill up faculties, develop the infrastructure, and compel institutions and faculties. Another big challenge to reform the education sector is existing policies that need to be amended timely. Some policymakers argue that it is difficult to change the policies unless and until there is a strong reason. It should be justified by its relevance and necessities. In this regard, this is an opportunity for policymakers to make radical changes in the policy which is also justified by the context and time. Figure 4 depicts the overall opportunities offered by Nepal's online education system.

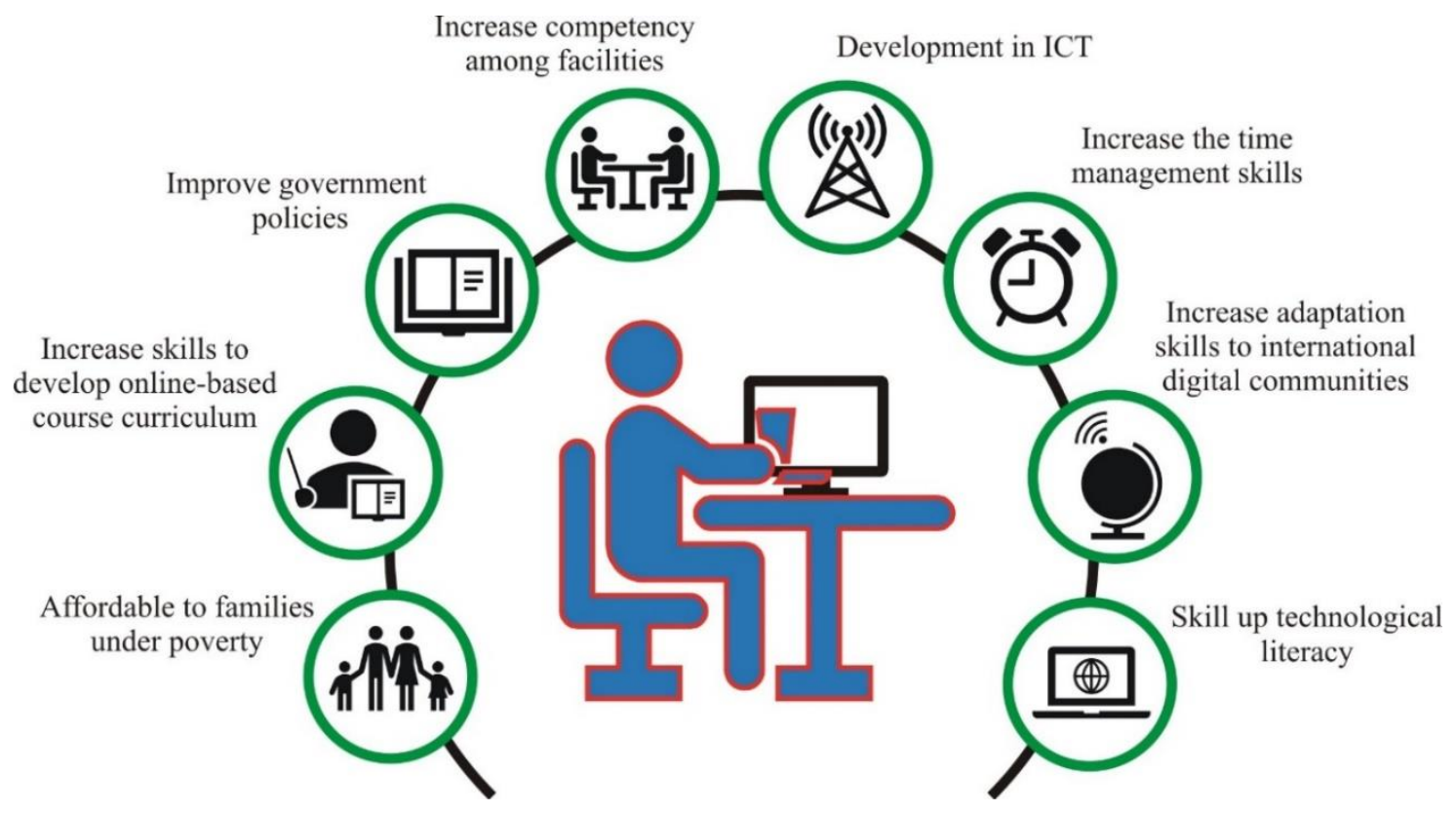

Figure 4. E-learning opportunities in Nepal

\section{CONCLUSIONS}

COVID-19 pandemic has caused disruptions in HEIs affecting more than $90 \%$ of the students across the world including Nepal. Despite tremendous educational progress, about half of the population is still illiterate, a situation aggravated by unequal socioeconomic situations and poor technological infrastructure. In Nepal, minimal students were getting opportunities for online classes, and a significant number of students were denied because of several aforementioned factors. Based on our research, $64.6 \%$ of respondents were dissatisfied with online education. About $28.8 \%$ of respondents reported online education as unappealing. To address this situation in the coming days, Nepal should focus on infrastructure development in higher education towards online facilities with adequate knowledge of new technology, organizing various motivational programs, provide training to faculties and students, increase collaboration with funding agencies, and so on. More emphasis should be given on clear institutional policy regarding the regulation of evaluation or examination systems in online classes. Future research should involve faculty members delving deeply into their teaching experiences during the epidemic to develop a set of practical recommendations for improving distance education.

\section{Funding and Conflicts of Interest}

This research did not receive any specific grant from funding agencies and author's team declares that there is no conflict of interest for this research. 


\section{REFERENCES}

Agormedah, E. K., Henaku, E. A., Ayite, D. M. K., \& Ansah, E. A. (2020). Online Learning in Higher Education during COVID-19 Pandemic: A case of Ghana. Journal of Educational Technology and Online Learning, https://doi.org/10.31681/jetol.726441

Al-Azzam, N., Elsalem, L., \& Gombedza, F. (2020). A cross-sectional study to determine factors affecting dental and medical students' preference for virtual learning during the COVID-19 outbreak. Heliyon, 6(12), e05704. https://doi.org/10.1016/j.heliyon.2020.e05704

Alsoud, A. R., \& Harasis, A. A. (2021). The Impact of COVID-19 Pandemic on Student's E-Learning Experience in Jordan. Journal of Theoretical and Applied Electronic Commerce Research, 16(5), 1404-1414. https://doi.org/10.3390/jtaer16050079

Anwar, M., Khan, A., \& Sultan, K. (2020). The barriers and challenges faced by students in online education during covid-19 pandemic in pakistan. 36(1), 11.

Azubuike, O. B., Adegboye, O., \& Quadri, H. (2021). Who gets to learn in a pandemic? Exploring the digital divide in remote learning during the COVID-19 pandemic in Nigeria. International Journal of Educational Research Open, 2-2, 100022. https://doi.org/10.1016/j.ijedro.2020.100022

Azzi-Huck, K., \& Shmis, T. (2020). Managing the impact of COVID-19 on education systems around the world: How countries are preparing, coping, and planning for recovery.

https://blogs.worldbank.org/education/managing-impact-covid-19-education-systemsaround-world-how-countries-are-preparing

Bao, W. (2020). COVID-19 and online teaching in higher education: A case study of Peking University. Human Behavior and Emerging Technologies, 2(2), 113-115. https://doi.org/10.1002/hbe2.191

Brueckner, J. K., \& Kim, H. (2001). Land Markets in the Harris-Todaro Model: A New Factor Equilibrating Rural-Urban Migration. Journal of Regional Science, 41(3), 507-520. https://doi.org/10.1111/0022-4146.00228

Burac, M. A. P., Fernandez, J. M., Cruz, M. M. A., \& Cruz, J. D. (2019). Assessing the impact of e-learning system of higher education institution's instructors and students. IOP Conference Series: Materials Science and Engineering, 482, 012009. https://doi.org/10.1088/1757899X/482/1/012009

Chaudhary, M. K. (2021). Impact of covid-19 on the higher education in nepal: the mindset of students and faculties towards online teaching learning practice. PalArch's Journal of Archaeology of Egypt / Egyptology, 18(1), 3936-3942.

Coman, C., Țîru, L. G., Meseșan-Schmitz, L., Stanciu, C., \& Bularca, M. C. (2020). Online Teaching and Learning in Higher Education during the Coronavirus Pandemic: Students' Perspective. Sustainability, 12(24), 10367. https://doi.org/10.3390/su122410367

DataReportal. (2021). Digital in Nepal: All the Statistics You Need in 2021. DataReportal - Global Digital Insights. https://datareportal.com/reports/digital-2021-nepal

Dawadi, S., Giri, R., \& Simkhada, P. (2020). Impact of COVID-19 on the Education Sector in NepalChallenges and Coping Strategies. https://doi.org/10.31124/advance.12344336.v1

Docebo. (2017). Docebo Elearning Trends Report 2017 / Massive Open Online Course / Educational Technology. Scribd. https://www.scribd.com/document/334568637/Docebo-ElearningTrends-Report-2017

Espino-Díaz, L., Fernandez-Caminero, G., Hernandez-Lloret, C.-M., Gonzalez-Gonzalez, H., \& AlvarezCastillo, J.-L. (2020). Analyzing the Impact of COVID-19 on Education Professionals. Toward a Paradigm Shift: ICT and Neuroeducation as a Binomial of Action. Sustainability, 12(14), 5646. https://doi.org/10.3390/su12145646 
Farooq, F., Rathore, F. A., \& Mansoor, S. N. (2020). Challenges of Online Medical Education in Pakistan During COVID-19 Pandemic. Journal of the College of Physicians and Surgeons Pakistan, 30(1), 67-69. https://doi.org/10.29271/icpsp.2020.Supp1.S67

GoN. (2020). The Official Portal of Government of Nepal. http://www.nepal.gov.np:8080/NationalPortal/view-page?id=125

Hebebci, M. T., Bertiz, Y., \& Alan, S. (2020). Investigation of Views of Students and Teachers on Distance Education Practices during the Coronavirus (COVID-19) Pandemic. International Journal of Technology in Education and Science, 4(4), 267-282. https://doi.org/10.46328/ijtes.v4i4.113

Huang, A. H. (1997). Challenges and Opportunities of Online Education. Journal of Educational Technology Systems, 25(3), 229-247. https://doi.org/10.2190/DE8W-DA78-FH16-5K89

Joshi, A., Vinay, M., \& Bhaskar, P. (2020). Impact of coronavirus pandemic on the Indian education sector: Perspectives of teachers on online teaching and assessments. Interactive Technology and Smart Education, ahead-of-print(ahead-of-print). https://doi.org/10.1108/ITSE-06-2020$\underline{0087}$

Kirsch, C., Engel de Abreu, P. M. J., Neumann, S., \& Wealer, C. (2021). Practices and experiences of distant education during the COVID-19 pandemic: The perspectives of six- to sixteen-year-olds from three high-income countries. International Journal of Educational Research Open, 2-2, 100049. https://doi.org/10.1016/j.ijedro.2021.100049

Koirala, D., Silwal, M., Gurung, S., Bhattarai, M., \& Kc, V. K. (2020). Perception towards Online Classes during COVID-19 among Nursing Students of a Medical College of Kaski District, Nepal. Journal of Biomedical Research \& Environmental Sciences, 1(6), 249-255.

https://doi.org/10.37871/jbres1151

Lorenza, L., \& Carter, D. (2021). Emergency online teaching during COVID-19: A case study of Australian tertiary students in teacher education and creative arts. International Journal of Educational Research Open, 2-2, 100057. https://doi.org/10.1016/j.ijedro.2021.100057

Maatuk, A. M., Elberkawi, E. K., Aljawarneh, S., Rashaideh, H., \& Alharbi, H. (2021). The COVID-19 pandemic and E-learning: Challenges and opportunities from the perspective of students and instructors. Journal of Computing in Higher Education. https://doi.org/10.1007/s12528-021$\underline{09274-2}$

Mishra, L., Gupta, T., \& Shree, A. (2020). Online teaching-learning in higher education during lockdown period of COVID-19 pandemic. International Journal of Educational Research Open, 1, 100012. https://doi.org/10.1016/j.ijedro.2020.100012

Motte-Signoret, E., Labbé, A., Benoist, G., Linglart, A., Gajdos, V., \& Lapillonne, A. (2021). Perception of medical education by learners and teachers during the COVID-19 pandemic: A cross-sectional survey of online teaching. Medical Education Online, 26(1), 1919042.

https://doi.org/10.1080/10872981.2021.1919042

National ICT Policy. (2015). Nepal's National Information and Communication Technology (ICT) Policy, 2015 (2072 BS) • TechSansar.com. https://techsansar.com/ict/nepal-ict-policy-2015/

Nepal, S., Atreya, A., Menezes, R. G., \& Joshi, R. R. (2020). Students' Perspective on Online Medical Education Amidst the COVID-19 Pandemic in Nepal. Journal of Nepal Health Research Council, 18(3), 551-555. https://doi.org/10.33314/jnhrc.v18i3.2851

Neupane, H. C., Sharma, K., \& Joshi, A. (2020). Readiness for the Online Classes during COVID-19 Pandemic among Students of Chitwan Medical College. Journal of Nepal Health Research Council, 18(2), 316-319. https://doi.org/10.33314/jnhrc.v18i2.2725

Nguyen, T. (2015). The Effectiveness of Online Learning: Beyond No Significant Difference and Future Horizons. 11(2), 11. 
Oyedotun, T. D. (2020). Sudden change of pedagogy in education driven by COVID-19: Perspectives and evaluation from a developing country. Research in Globalization, 2, 100029.

https://doi.org/10.1016/j.resglo.2020.100029

Pangeni, S. K. (2017). Open and Distance Learning: Cultural Practices in Nepal. European Journal of Open, Distance and E-Learning, 19(2), 32-45. https://doi.org/10.1515/eurodl-2016-0006

Patricia Aguilera-Hermida, A. (2020). College students' use and acceptance of emergency online learning due to COVID-19. International Journal of Educational Research Open, 1, 100011. https://doi.org/10.1016/j.ijedro.2020.100011

Paudel, P. (2020). Online Education: Benefits, Challenges and Strategies During and After COVID-19 in Higher Education. International Journal on Studies in Education, 3(2), 70-85. https://doi.org/10.46328/ijonse.32

Radha, R. (2020). E-Learning during Lockdown of Covid-19 Pandemic: A Global Perspective. International Journal of Control and Automation, 13(4), 1088-1099.

Rashid, S., \& Yadav, S. S. (2020). Impact of Covid-19 Pandemic on Higher Education and Research. Indian Journal of Human Development, 14(2), 340-343. https://doi.org/10.1177/0973703020946700

Sharma, A., \& Kim, Y. (2016). Information Communication Technology Development in Nepal. Institute for Poverty Alleviation and International Development, 25, 101-141. https://doi.org/10.18350/ipaid.2016.25.1.101

Sharma, G., \& Bhatta, M. (2018). Implementing E-Learning in Far Western Region of Nepal. Advances in Computer Sciences, 1. https://doi.org/10.31021/acs.20181111

Shrestha, R. M., Shrestha, S., Acharya, A., \& Gupta, A. (2020). Online Education Status at Dental Colleges During COVID-19 Pandemic in Nepal. Kathmandu University Medical Journal (KUMJ), 18(70), 15-20.

Sigdel, S., Ozaki, A., Dhakal, R., Pradhan, B., \& Tanimoto, T. (2021). Medical Education in Nepal: Impact and Challenges of the COVID-19 Pandemic. Academic Medicine, 96(3), 340-342. https://doi.org/10.1097/ACM.0000000000003888

Sokal, L., Trudel, L. E., \& Babb, J. (2020). Canadian teachers' attitudes toward change, efficacy, and burnout during the COVID-19 pandemic. International Journal of Educational Research Open, 1, 100016. https://doi.org/10.1016/j.ijedro.2020.100016

Statista. (2021). Nepal: Internet penetration rate 2019. Statista. https://www.statista.com/statistics/765517/internet-penetration-rate-nepal/

Sun, A., \& Chen, X. (2016). Online Education and Its Effective Practice: A Research Review. Journal of Information Technology Education: Research, 15, 157-190.

Tadesse, S., \& Muluye, W. (2020). The Impact of COVID-19 Pandemic on Education System in Developing Countries: A Review. Open Journal of Social Sciences, 8(10), 159-170. https://doi.org/10.4236/jss.2020.810011

Tang, Y. M., Chen, P. C., Law, K. M. Y., Wu, C. H., Lau, Y., Guan, J., He, D., \& Ho, G. T. S. (2021). Comparative analysis of Student's live online learning readiness during the coronavirus (COVID-19) pandemic in the higher education sector. Computers \& Education, 168, 104211. https://doi.org/10.1016/j.compedu.2021.104211

Thapa, S. (2015). Relationship between education and poverty in Nepal. Economic Journal of Development Issues, 15. https://doi.org/10.3126/ejdi.v15i1-2.11873

Thapa, V. (2020). Possibilities of e-learning in higher education of nepal. https://doi.org/10.13140/RG.2.2.24345.77923 
The World Bank. (2020). GDP per capita (current US\$)—Nepal / Data. https://data.worldbank.org/indicator/NY.GDP.PCAP.CD?locations=NP

Tuladhar, S. L., Pradhan, D., Parajuli, U., Manandhar, P., \& Subedi, N. (2020). Study on the effectiveness of online classes for undergraduate medical and dental students of Gandaki Medical College during COVID 19 pandemic period in Nepal. Orthodontic Journal of Nepal, 10(2), 36-40. https://doi.org/10.3126/ojn.v10i2.31146

UGC. (2020a). Agreement between UGC and NT to Facilitate Teaching and Learning. https://ugcnepal.edu.np/singlenews/25

UGC. (2020b). Restructuring and Reallocating funding for Alternative Mode of Learning in Response Covid-19. https://www.ugcnepal.edu.np/singlenews/19

UNESCO. (2021, March 19). One year into COVID-19 education disruption: Where do we stand? UNESCO. https://en.unesco.org/news/one-year-covid-19-education-disruption-where-do-we-stand

Viner, R. M., Russell, S. J., Croker, H., Packer, J., Ward, J., Stansfield, C., Mytton, O., Bonell, C., \& Booy, R. (2020). School closure and management practices during coronavirus outbreaks including COVID-19: A rapid systematic review. The Lancet Child \& Adolescent Health, 4(5), 397-404. https://doi.org/10.1016/S2352-4642(20)30095-X

Zarei, S., \& Mohammadi, S. (2021). Challenges of higher education related to e-learning in developing countries during COVID-19 spread: A review of the perspectives of students, instructors, policymakers, and ICT experts. Environmental Science and Pollution Research International. https://doi.org/10.1007/s11356-021-14647-2

Zhang, W., Wang, Y., Yang, L., \& Wang, C. (2020). Suspending Classes Without Stopping Learning: China's Education Emergency Management Policy in the COVID-19 Outbreak. Journal of Risk and Financial Management, 13(3), 55. https://doi.org/10.3390/jrfm13030055

\section{ABBREVIATIONS}

ANOVA: Analysis of Variance;

- CD: Compact Disc;

- COVID-19: Coronavirus Disease 2019;

- DEC: Distance Education Center;

- DVD: Digital Versatile Disc;

- HE: Higher Education;

- HEIs: Higher Education Institutions;

- MOODLE: Modular ObjectOriented Dynamic Learning Environment;

- ICT: Information and Communications Technology;

- KU: Kathmandu University;

- LDC: Least Developing Country;

- LTE: Long Term Evolution;

- LMS: Learning Management System;

- PGD: Postgraduate Diploma;

- SARS-CoV-2: Severe Acute Respiratory Syndrome Coronavirus-2;

- SDGs: Sustainable development Goals;

- SES: Socioeconomic Status;
SIM: Subscriber Identification Module;

SPSS: Statistical Package for the Social Sciences;

TU: Tribhuvan University;

- UGC: University Grants Commission;

- UNESCO: United Nations Educational, Scientific and Cultural Organization;

- WHO: World Health Organization. 